\title{
Gender DifFERENCES In STUdENT ATTITUdES TOWARDS Sexual Appeals in Print Advertising
}

\author{
Philippa Klug and Debbie Vigar-Ellis
}

School of Management, Information Technology and Governance, University of KwaZulu-Natal, Pietermartizburg

Accepted: May 2012

\begin{abstract}
Sexuality is a widely used appeal in advertising today. The aim of this research was to establish whether or not this form of advertising connects with South African students and whether gender differences existed. A triangulated research design with data collected in focus groups, was used. The findings generally indicated negative attitudes towards sexual appeals in advertising. The main difference in gender responses was that males responded more negatively to adverts that contained male models as opposed to female models, whereas, women responded in similar ways regardless of the gender of the model.
\end{abstract}

Key words: sexual appeals, gender differences

JEL: M370

\section{1}

\section{Introduction}

The use of sexual appeals in advertising is common (Duncan, 2002). Sexual appeals in advertising have the ability to 'grab' the consumer's attention (Ouwersloot \& Duncan, 2008). According to LaTour and Henthorne (1994), sex appeal is becoming more overt as advertisers attempt to find ways to break through the media clutter. For example, Jones and Reid (2010:19) indicate the rise in 'raunch culture', where 'a new female stereotype has emerged in advertising - the 'lusty, busty exhibitionist' who exudes sexual power and confidence'. The purpose of this paper is to explore gender differences in the responses of students at a university in South Africa, to advertisements using sexual appeals.

\section{2}

\section{Sexual appeal}

Sexual appeal is one of seven appeals used successfully in advertising (Clow \& Baack, 2007). These appeals include fear, humour, sex, music, rationality, emotion, and scarcity. Certain appeals are more effective than others for particular circumstances. Thus the advertiser's main goal is to ensure the appropriate appeal is used for the brand or product. 'The objective of an appeal is to arouse the need and desire for the product in the target audience' (Trehan \& Trehan, 2007:85). The appeal should match the characteristics of the target market and the product features (Trehan \& Trehan, 2007).

Reichert (2003:para2) defines sexual appeal as 'persuasive messages integrated with sexual information into an overall message about a brand'. He further defines sexual information as 'any representation that portrays or implies sexual interest, behaviour, or motivation' (Reichert, 2003:para3). Nudity and sexual appeals are one of the most widely used appeals and are becoming increasingly explicit (Shimp, 2008). Paarsonen, Nikunen, and Saaremaa, (2007) suggest that society is more comfortable with sexuality:

From the hypersexualised star image of Paris Hilton to Madame Tussaud's wax modelling of porn star Jenna Jameson, texts citing pornographic styles, gestures and aesthetics - and to a degree pornography itself - have become a staple features of popular media culture in Western societies (Paasonen et al., 2007:1). 


\section{3 \\ Types of sexual appeals}

Ouwersloot and Duncan (2008) identify forms of sexual appeal: subliminal, nudity and eroticism.

\subsection{Subliminal techniques}

Subliminal techniques involve sexual cues that only affect the viewer subconsciously, thus the viewers are not aware they are receiving the message (Shimp, 2008). Types of embeds include genitalia shapes and sexual acts or positions (Reichert, 2003). Clow and Baack (2007) suggest the sexuality in subliminal advertising is too vague and consumers therefore pay little attention to this form of advertising and thus it is ineffective. Due to the difficulty with measurement of subliminal messages, these did not form part of study reported on in this paper.

\subsection{Nudity and partial nudity}

Nudity and partial nudity is the use of naked bodies in advertisements (Ouwersloot \& Duncan, 2008). This type of sexual appeal is often used to sell products with strong sexual connection such as fragrances and lingerie (Clow \& Baack, 2007) but has also been used to sell products that are unrelated or irrelevant to sex such as cars (Ouwersloot \& Duncan, 2008). Moyer (2003) has suggested that the use of sex appeal can sell anything from toothpaste to aluminium. This type of advertising usually seeks a sexual response rather than to inform the consumer about the product (Clow \& Baack, 2007).

Lombardot's research found that advertisements with nudity or partial nudity containing the opposite sex, increase attention-getting (Lombardot, 2007). This result was true for both men and women thus suggesting that nudity is a valid way to gain both men and women's attention. Lombardot (2007) suggests that it is an emotional response that occurs before any cognitive process of the advertisement has occurred. The findings also specified that the presence of nudity in an advertisement where the product is not related (according to the consumers) can raise a negative response to the advertisement (Lombardot, 2007). Ouwersloot and Duncan (2008) support this conclusion in saying that unrelated sexual images can overpower the primary brand message.

\subsection{Eroticism}

Ouwersloot and Duncan (2008) define eroticism as the sexual desire between partners (opposite or same sex). Reichert (2003) and Clow and Baack (2007) suggest that sexual behaviour, or overt sexuality, can be either 'individual or interpersonal' (Reichert, 2003). Advertising using this type of appeal may show sexually provocative behaviour with, or without, the act of sex. This includes poses or positions performed by an individual or pairs (Reichert, 2003). Reichert (2003) distinguishes the overt sexual appeal from the sexually suggestive appeal. With the sexually suggestive approach the sexuality is more subtle, but the sexual connotation is still present and clear (Reichert, 2003). Sexual suggestiveness is a less controversial form of using sexuality as it is not as blatant as an overt sexual approach (Clow \& Baack, 2007). The goal behind sexual suggestiveness is to trigger sexual thoughts and make sexual references. Advertisers often do this through innuendo and illusions (Reichert, 2003). Cebrezyski (2000) makes a similar distinction between 'sex' advertisements and 'sexiness' advertisements. He say the difference between them is that sexiness always leaves something to the imagination, while 'sex' advertisements just leave the viewer feeling violated (Cebrezyski, 2000).

\section{4}

\section{The effectiveness of sexual appeals}

There is a lot of contradictory literature on the effectiveness of sexual appeals in advertising.

According to Shimp (2008) sexual appeal in advertising has the ability to attract and hold attention. Reichert (2003) describes this 'attention grabbing' advantage as 'borrowed interest' as the interest created through the sexuality transfers into interest in the brand or product. Wells, Burnett and Moriarty (2000) suggest that advertisements with more explicit or controversial sexual appeals are more interesting to consumers (both male and female). On the other hand, it has been argued that this interest is only short-term and no long-term sustainable interest is created through sexual appeals (Shimp, 2008).

Clow and Baack (2007) also suggest that although sexual appeals are extremely successful 
at 'grabbing' the consumer's attention, there is often a gap between brand recall and the advertisement (Clow \& Baack, 2007) and these advertisements do not increase the information transferred to consumers (Wells et al., 2000; Clow \& Baack, 2007). Thus consumers are often more focused on the sexual appeal, rather than the brand, and this leads to low brand recall, especially if it is difficult to find the link to sex in the product being advertised (Clow \& Baack, 2007). Several authors have indicated that there must be a clear link between sex and the product, for the appeal to be effective, as without this there will be little long-term return from this form of advertising (e.g. Veloutsou \& Ahmed, 2005; Ouwersloot \& Duncan, 2008). Putrevu's (2008) research showed that sexual appeals are appropriate for lowinvolvement consumers, as they generate higher recall and recognition, more cognitive response and positive attitudes and purchase intent. High-involvement consumers on the other hand, had higher purchase intent and more positive attitudes toward nonsexual appeals, that is, those including other forms of appeal such as humour. However, Sengupta and Gorn's (2002) research indicates that advertisements today are generally processed in a cursory, low-involvement manner, and thus sexual appeals may be effective.

Negative publicity from extremely sexual advertisements can decrease an organisation's sales and, in turn, affect their reputation (Belch $\&$ Belch, 2007). The Puma shoe and clothing brand 'launch' advertisement with a girl on her knees with a male standing in front of her with his crotch in her face, hinted (quite directly) at the girl performing oral sex on the man. However, the image is cut off at the girl's shoulders. This highly racy advertisement generated a huge amount of negative publicity, despite the debate suggesting this advertisement was fake (Walker, 2003).

\section{5}

\section{Gender reactions to sexual appeals}

LaTour and Henthorne's (1994) research supports the idea that overtly sexual advertisements can have a negative impact on an organisation's sales and reputation. Their study found that both men and women had negative reactions to overt sexuality in terms of intent to purchase and brand reputation. Sengupta and Dahl (2008) also found no gender differences to product-irrelevant explicit sexual appeals under cognitively unconstrained conditions, that is, where ads are processed in some depth (Sengupta \& Gorn, 2002). LaTour and Henthorne (1994) also found that both genders believe that overly sexual advertisements raise ethical concerns. However, the research still indicates the success it achieves at 'grabbing' the attention of both genders (LaTour \& Henthorne, 1994). Thus both men and women appear to react negatively at least to overt sexuality in advertising. However, research also indicates that there are differences between the genders' reactions to sexual appeals.

Sengupa and Dahl (2008), for example, argue that the literature on human sexuality indicates that men have more positive attitudes to sex per se and to sexually explicit stimuli, than women do. These authors found that under conditions of constrained processing, that is, limited time that elicits instinctive or spontaneous reactions, females evaluated an explicit sexual advertisement less positively than males did (Sengupta \& Dahl, 2008). Males evaluated sexual advertisements more favourably than nonsexual advertisements while the opposite occurred for females. However, women have been found to respond more positively towards the sexual appeal when there was a good fit between the advertisement and the product, and negatively when the fit was weak, while males responded positively regardless of the product fit (Putrevu, 2008). However, Sengupta and Dahl (2008) found that even when the advertisement was product-relevant, female attitudes were less favourable than those of males. They explain that due to constrained processing (i.e. affective rather than cognitive processing), attitudes toward advertisements are driven by spontaneous affective reactions and females react more negatively to sexual content than males do. Thus although the response may be less negative for a product-relevant sexual advertisement, the response is still negative.

Bird, Caldwell and DeFanti (2008) found both men and women were unhappy with the overt sexuality of the male fragrance advertisements. This is interesting as fragrances are generally believed to be a product where there 
is a good fit with a sexual appeal (Putrevu, 2008). Thus research appears to be contradictory.

Response to sexual appeals also appears to be influenced by the gender of the model in the advertisement. Research conducted in China by Liu, Li and Cheng (2006) found that when exposed to advertisements with low levels of sexual appeal, male and female responses differed significantly only when the respondents were exposed to male models. Thus male models in advertisements with a low level of sex appeal could attract female consumers but men did not find advertisements containing male models appealing irrespective of the level of sexual appeal. This is supported by Israel and Strassberg's (2009) research that found that men were more uncomfortable than women in finding same-sex models sexually appealing.

For high levels of sexual appeal Liu et al. (2006) found no difference in responses when the respondents were exposed to advertisements featuring male models, in that both males and females responded with the least amount of interest, or even negatively, to the male model featured by high sex appeal advertisement. In two cross-country studies by Liu, Cheng and Li (2009) and Jones and Reid (2010), it was found that irrespective of the country, female consumers have significantly less-favourable attitudes towards advertisements containing high sex appeals and female models, as compared to male consumers. This supports Taflinger's (1996) finding that while advertisements with high sexual appeal featuring female models may attract males, they may be offensive to females.

The above studies reflect contradictory results and are also all studies conducted in other countries. No similar studies could be found looking specifically at gender differences amongst South African respondents. Therefore the purpose of this study was to determine gender differences in South African student perceptions of various forms of sexual appeal in print advertisements (see appendix).

\section{6}

\section{Objectives}

For this paper four specific objectives are reported on. These were to determine: a) the extent to which respondents found the advertisements offensive;

b) the extent to which the advertisements appealed to the respondents;

c) the extent to which respondents felt the advertisements were appropriate for the product being advertised; and

d) whether males and females differed significantly in their responses to the above.

\section{7}

\section{Research design}

For the purpose of this research a triangulation design was utilised. 'Triangulation, in its most common form, refers to the uses of multiple means of data collection to explore a single phenomenon' (Gratton \& Jones, 2004:18). Triangulation involves combining both qualitative and quantitative data either sequentially or in parallel (Neuman, 2006). The researchers thus collected data using both qualitative and quantitative methods. Polit and Beck (2004) suggest that triangulation can increase credibility of research as it captures a more complete and contextualised understanding of the data. Therefore the triangulation can result in valid research and a more comprehensive understanding of a particular topic (Polit \& Beck, 2004).

The qualitative and quantitative data were collected from a short questionnaire in a written form and from verbal responses in focus groups. The research conducted was exploratory as its aim was to gain a deeper understanding of attitudes toward sexual appeals. The research was approved by the UKZN Faculty Ethical Clearance Committee before the field research commenced. All respondents were briefed on the purpose of the study and were issued with informed consent documents before the focus groups started.

\subsection{Sample size}

This sample included students aged 18 to 25 , from the University of KwaZulu-Natal Pietermaritzburg campus. Non-probability sampling, and more specifically convenience sampling, was used to select the respondents. The researchers were of the opinion that as the majority of sexual advertisements are targeted at the youth, their attitudes towards the topic 
would be most valuable to the research and thus a student sample was used. However, due to the sexual nature and explicitness of the selected advertisements, all participants had to be 18 years or older. A cross-section of classes across all years of study, and the four faculties represented at the university, ensured exposure to a diverse sampling frame in terms of gender, race and age demographics. In the classes, students were informed about the study and asked to volunteer for the focus groups. There were a total of six focus group sessions with 57 participants, 20 males and 37 females.

\subsection{Data collection instruments}

At the start of each focus group, respondents were asked to complete a short questionnaire. This questionnaire included structured questions, with structured answers, in the form of Likert scale questions. It provided the researchers with respondents' attitude towards each advertisement, and thus the individual's responses were not influenced by the rest of the group. The respondents were shown one advertisement at a time and answered the short questionnaire for each advertisement. Advertisements were shown in the order they are discussed below, in each focus group. The advertisements were shown in the same order to ensure unnecessary bias wasn't introduced across the focus groups. Once this process was complete, the discussion section of the focus group commenced. The researcher acted as a moderator during the discussions and introduced new questions relating to the different advertisements. The questions were derived from the objectives and the literature review. The researchers used a semi-structured interview technique for the focus groups, having both structured and open-ended questions to stimulate discussion and debate. This ensured that the respondents covered all required questions but were still able to discuss each question freely within reasonable time constraints.

\subsection{Advertisement selection}

The advertisements were selected to cover the different types of sexual appeal, varying links to sex, both male and female models and both male and female target audiences. All the advertisements selected were foreign to South
African media as the researchers did not want respondents to have seen the advertisements before and have developed preconceived ideas about them. Advertisements meeting the criteria above were selected from available foreign print media. The advertisements can be found in the appendix.

The first advertisement was advertising the French Rugby Team. Two of the French rugby players are sitting together naked with their arms around each other, in what appears to be a change room. This advertisement contained only male models and has a target audience which is mixed although possibly maledominated. There is no link between the product and sex and the type of sexual appeal used is nudity.

The Durex advertisement has a direct link to sex as it is promoting extra large condoms. This image contains a close-up of a woman's mouth with plasters on the edge of her lips with a tag line that reads 'really big...'. The advertisement contains only a female model and is targeted at men. The appeal may be defined as eroticism and specifically overt sexuality as sexual behaviour is clearly implied (Clow \& Baack, 2007).

The Peugeot 207GTI advertisement has an unclear link to sex. A couple are in a suggestive position on a bed in their underwear, both wearing helmets. This slogan reads 'The Peugeot 207GTI. Sexy gets fast'. Thus this advertisement contains models of both genders and is targeted at both genders. The appeal would also be categorised as eroticism. This advertisement would also be classified as containing overt sexuality due to the positions of the models clearly implying sexual behaviour.

In the fourth advertisement, a fragrance for men made by Tom Ford is being advertised with an image of a woman's body from the waist down, cut off at the knees. There is a fragrance bottle strategically placed over the female's genitals. The image is extremely close up and clear. The tag line reads 'The first fragrance for men by Tom Ford'. Clow and Baack (2007) suggest that fragrances have a strong link to sex. The advertisement contains a female model and the target audience is men. This advertisement uses a nudity-based sexual appeal. 
The final advertisement selected was a Gucci advertisement. A woman is up against a wall, pulling her underwear down to reveal her pubic area, which has a $G$ shaved into the hair. A fully clothed man is kneeling in front of her. This advertisement was selected as it clearly relies on overt sexuality, also a form of eroticism. The advertisement also includes partial nudity in the female model. Gucci is a clothing brand and thus there is a link to sexuality, although it is vague. Models of both genders are included and the product target is women.

Thus two of the five selected advertisements contained female models only (Durex and Tom Ford), while one advertisement contained only male models (The French Rugby Team). The remaining two advertisements (Gucci and Peugeot) contained both genders. This slightly skewed selection is justified as women are portrayed more frequently in advertising than men (Reichert et al., 1999).

A pilot study of the focus-group procedure was conducted with six participants. The pilot session followed the same structure as the focus groups, with the short questionnaire first, followed by a focus-group discussion. The pilot was successful and there were only a few changes made to the short questionnaire conducted prior to the start of the focus group.

\subsection{Data analysis}

Quantitative data was analysed using descriptive statistics and the Mann-Whitney $U$ test was used to determine the significance of gender differences. A Man Whitney U test is used to compare two samples that are unrelated, such as males and females, to identify significant differences (Corder \& Foreman, 2009:57). In order for a response to be significant, the test score needs to be less than 0.05 (Corder \& Foreman, 2009:57).

Thematic analysis was selected to analyse the qualitative data. In thematic analysis patterns or themes are identified within the qualitative data (Welman, Kruger \& Mitchell, 2005:221). This analytical tool is useful for identifying attitudes and beliefs (Marks \& Yardley, 2004:58). As mentioned previously, the collection of both qualitative and quantitative data allowed for triangulation.

\section{8}

\section{Discussion of results and conclusions}

As the focus of this paper is on the gender differences, this section looks at findings related to the first three objectives and, within each of these, discusses gender differences.

\subsection{The extent to which respondents found the advertisements offensive}

Perceptions of the advertisements were measured using Likert scale questions in the questionnaire as well as discussion questions in the focus group discussion.

\section{Table 1}

Statement 1: I was offended by this advertisement

\begin{tabular}{|l|c|c|c|c|c|}
\hline & $\begin{array}{c}\text { Advertisement } \\
\text { 1: FRT }\end{array}$ & $\begin{array}{c}\text { Advertisement } \\
\text { 2: Durex }\end{array}$ & $\begin{array}{c}\text { Advertisement } \\
\text { 3: Peugeot }\end{array}$ & $\begin{array}{c}\text { Advertisement } \\
\text { 4: Tom Ford }\end{array}$ & $\begin{array}{c}\text { Advertisement } \\
\text { 5: Gucci }\end{array}$ \\
\cline { 2 - 6 } & Per cent & Per cent & Per cent & Per cent & Per cent \\
\hline 1. Strongly agree & 17 & 14 & 0 & 39 & 18 \\
\hline 2. Agree & 32 & 19 & 2 & 26 & 23 \\
\hline 3. Neither A nor D & 14 & 21 & 12 & 7 & 28 \\
\hline 4. Disagree & 35 & 40 & 25 & 18 & 26 \\
\hline 5. Strongly disagree & 2 & 5 & 4.00 & 2.37 & 5 \\
\hline Mean & 2.72 & 3.11 & 0.681 & 1.410 & 2.81 \\
\hline Std dev & 1.176 & 1.263 & & 1.187 \\
\hline
\end{tabular}

The results show that three of the five advertisements were perceived to be offensive to a larger portion of respondents, that is, more respondents agreed or strongly agreed that the advertisements were offensive, than disagreed.
These were the Tom Ford advertisement, which had the ratio of $65: 29$, that is, 65 per cent of respondents agreed that the advertisement was offensive to some extent, compared to 29 per cent who disagreed to some extent; 
the French Rugby team advertisement with the ratio 49:37 and the Gucci advertisement with 42:31. The Tom Ford advertisement was offensive to the largest proportion of respondents with 65 per cent, while for the Peugeot advertisement, 85 per cent of respondents disagreed that the advertisement was offensive.

The differences in perceived offensiveness may be due to the types of sexual appeal used. Gucci, the French Rugby Team and Tom Ford advertisements all use nudity or partial nudity. Nudity usually seeks a sexual response rather than to inform the consumer about the product (Clow \& Baack, 2007). While the Tom Ford and French Rugby Team advertisements use only nudity as their sexual appeal, the Gucci advertisement combines this with eroticism as the male kneeling in front of the standing female hints at oral sex. This advertisement is thus also an example of overt sexuality using Reichert's (2003) definition of overt sexuality as being to involve sexually provocative behaviour with or without the sex act.

The Durex advertisement also used overt sexuality as a form of eroticism. However, in this advertisement it is not accompanied by nudity, nor is the sexuality as obvious or blatant. Compared with the Gucci advertisement, which also uses eroticism, the response to the offensiveness of the Durex advertisement, was on average, neutral, while the response to the Gucci advertisement was that it was perceived to be slightly more offensive. The Peugeot advertisement uses overt sexuality as the couple are in a sexually suggestive position in their underwear on a bed. Interestingly, the Peugeot advertisement was found to be the least offensive.

When asked in the focus group discussions about what aspects of the advertisements offended the respondents, the two main themes that emerged from the thematic analysis were that the advertisements were too explicit (56 per cent of the responses) and that there was too much body exposure (44 per cent). Respondents commented that 'when you visually see the sexuality' and it is 'blatantly abused' or 'overly explicit' then it is offensive. With regard to the excessive body exposure, respondents commented that 'I just don't like someone showing that part of their body' and 'they show too much' like 'starting to see pubes [public hairs]', then it is offensive. Thus it appears that nudity is more offensive than appeals which relate to sexual behaviour.

Looking at the Mann-Whitney sig. scores in Table 2, it can be seen that there were significant differences between the responses of males and females to the extent of offensiveness in all the advertisements. This is because the sig. scores are all less than 0.05 (Corder \& Foreman, 2009).

Table 2

Gender differences: statement 1: I was offended by this advertisement

\begin{tabular}{|c|c|c|c|c|c|c|c|c|c|c|}
\hline & \multicolumn{2}{|c|}{$\begin{array}{c}\text { Advertisement } \\
\text { 1: FRT }\end{array}$} & \multicolumn{2}{|c|}{$\begin{array}{l}\text { Advertisement } \\
\text { 2: Durex }\end{array}$} & \multicolumn{2}{|c|}{$\begin{array}{l}\text { Advertisement } \\
\text { 3: Peugeot }\end{array}$} & \multicolumn{2}{|c|}{$\begin{array}{l}\text { Advertisement } \\
\text { 4: Tom Ford }\end{array}$} & \multicolumn{2}{|c|}{$\begin{array}{l}\text { Advertisement } \\
\text { 5: Gucci }\end{array}$} \\
\hline & $\mathbf{F}$ & M & $\mathbf{F}$ & $\mathbf{M}$ & $\mathbf{F}$ & M & $\mathbf{F}$ & M & $\mathbf{F}$ & M \\
\hline Mean & 2.97 & 2.25 & 2.73 & 3.80 & 3.84 & 4.30 & 1.65 & 3.70 & 2.32 & 3.70 \\
\hline Std dev & 1.118 & 1.164 & 1.170 & 1.152 & 0.646 & 0.657 & 0.919 & 1.174 & 1.029 & 0.923 \\
\hline Mann-Whitney sig score & & 0.028 & & 0.002 & & 0.013 & & 0 & & 0 \\
\hline
\end{tabular}

In all except the French Rugby Team advertisement, males were less offended by the advertisements than females were. For the French Rugby Team advertisement, females had a higher mean of 2.97 , that is, closer to neutral than males who tended to agree more strongly (mean of 2.25) that the advertisement was offensive. As a reminder, the scale was 1 $=$ strongly agree to $5=$ strongly disagree.

Females, on average, agreed that the Tom Ford and Gucci advertisements were most offensive to them while males disagreed on average that these advertisements were offensive. For the Durex advertisement, females, were on average, closer to neutral while males were on average not offended by the advertisement.

Thus to conclude regarding the offensiveness of print advertisements using sexual appeals, the results indicate that nudity, as a type of sexual appeal, is more offensive than eroticism, and males are generally less 
offended than females by advertisements using sexual appeals. However, there is one exception and that is where the models in the advertisement are males. In such a case, the male respondents were more offended than female respondents. This finding appears to support Taflinger's (1996) finding that while advertisements with high sexual appeal featuring female models may attract males they may be offensive to females. Advertisements that are offensive are risky because, as Clow and
Back (2007) point out, this can lead to the tarnishing of the brand name, as well as generating bad publicity (Walker, 2003) and decreasing sales and the organisation's reputation (Belch \& Belch, 2007).

\subsection{The extent to which respondents found the advertisements appealing}

The second objective of this study was to determine the extent to which the respondents found the advertisements to be appealing.

Table 3

Statement 2: this advertisement was appealing

\begin{tabular}{|l|c|c|c|c|c|}
\hline & $\begin{array}{c}\text { Advertisement } \\
\text { 1: FRT }\end{array}$ & $\begin{array}{c}\text { Advertisement } \\
\text { 2: Durex }\end{array}$ & $\begin{array}{c}\text { Advertisement } \\
\text { 3: Peugeot }\end{array}$ & $\begin{array}{c}\text { Advertisement } \\
\text { 4: Tom Ford }\end{array}$ & $\begin{array}{c}\text { Advertisement } \\
\text { 5: Gucci }\end{array}$ \\
\hline Per cent & Per cent & Per cent & Per cent & Per cent \\
\hline 1. Strongly agree & 5 & 7 & 4 & 12 & 7 \\
\hline 2. Agree & 7 & 19 & 23 & 19 & 18 \\
\hline 3. Neither A nor D & 7 & 23 & 26 & 7 & 21 \\
\hline 4. Disagree & 49 & 32 & 28 & 28 & 37 \\
\hline 5. Strongly Disagree & 32 & 19 & 19 & 33 & 18 \\
\hline Mean & 3.95 & 3.23 & 3.33 & 3.51 & 3.42 \\
\hline Std dev & 1.076 & 1.350 & 1.155 & 1.441 & 1.164 \\
\hline
\end{tabular}

Overall, respondents did not find these advertisements appealing, and the level of disagreement with the statement was greater than the level of agreement across all the advertisements. The least appealing, or the advertisement with the greatest amount of disagreement that the advertisement was appealing, was the French Rugby Team advertisement, where 81 per cent of respondents disagreed that it was appealing. This is compared with only 12 per cent of respondents who indicated that they agreed that this advertisement was appealing. The ratio of disagree to agree for the Durex advertisement was 51:26, for the Peugeot advertisement 47:27, for the Tom Ford advertisement, 61:31 and for the Gucci advertisement 55:25.

In the focus-group discussions, respondents were asked what their immediate reaction to the advertisements was. The most common response (47 per cent of all the responses given) was that there was too much sexuality. Respondents made comments such as 'they are very explicit', 'sleazy', 'too graphic' and 'gross'. The majority of the responses to the advertisements were negative. When asked when, or under what circumstances, advertisements with sexual appeals would be more appealing, respondents said that these advertisements were likely to be more appealing when they were targeted at men and appropriate to the product. The latter issue is addressed under Objective 3.

Table 4 indicates that males and females differed significantly in their perceptions of the appeal of all, except the Peugeot advertisement, where they were generally neutral on the appeal of the advertisement.

Male respondents strongly disagreed (mean $=4.60)$ that the French Rugby Team advertisement was appealing, while females who also did not agree that the advertisement was appealing (mean $=3.59)$, did not feel as strongly as the males did. The low standard deviation for the male scores also indicates strong consistency amongst the male respondents. For the other three advertisements with significant differences, that is, Durex, Tom Ford and Gucci, males, on average, found the advertisements significantly more appealing than females did. Males actually found these advertisements appealing, on average, with mean scores between 2.20 and 2.35. This supports the qualitative data which 
indicated that respondents felt advertisements with sexual appeals would be more appealing when the target audience was men. Certainly the Durex and Tom Ford advertisements, which are targeted to men, support this finding.

Table 4

Gender differences: statement 2: this advertisement was appealing

\begin{tabular}{|l|c|c|c|c|c|c|c|c|c|c|}
\hline & \multicolumn{2}{|c|}{$\begin{array}{c}\text { Advertisement } \\
\text { 1: FRT }\end{array}$} & \multicolumn{2}{c|}{$\begin{array}{c}\text { Advertisement } \\
\text { 2: Durex }\end{array}$} & \multicolumn{2}{c|}{$\begin{array}{c}\text { Advertisement } \\
\text { 3: Peugeot }\end{array}$} & \multicolumn{2}{c|}{$\begin{array}{c}\text { Advertisement } \\
\text { 4: Tom Ford }\end{array}$} & \multicolumn{2}{c|}{$\begin{array}{c}\text { Advertisement } \\
\text { 5: Gucci }\end{array}$} \\
\cline { 2 - 12 } & F & M & F & M & F & M & F & M & F & M \\
\hline Mean & 3.59 & 4.60 & 3.78 & 2.20 & 3.43 & 3.15 & 4.22 & 2.20 & 4.00 & 2.35 \\
\hline Std dev & 1.117 & 0.598 & 0.976 & 1.361 & 1.094 & 1.268 & 1.031 & 1.152 & 0.782 & 0.988 \\
\hline Mann-Whitney sig score & & 0 & & 0 & & 0.37 & & 0 & & 0 \\
\hline
\end{tabular}

To conclude on the appeal of print advertisements using sexual appeals, overall the results indicate that as long as the models are not males on their own, that is, not with a female model accompanying them, as was the case with the French Rugby team advertisement, then males found the advertisements more appealing than females did. Females were either neutral, as with the Peugeot advertisement, or did not agree that the advertisements were appealing. In particular, the Tom Ford and Gucci advertisements, which contained higher levels of female nudity, were found to be least appealing. Males, on the other hand, found the Tom Ford, Gucci and Durex advertisements appealing and only found the French Rugby Team advertisement, containing the male models, not appealing. Overall this supports Putrevu
(2008) and Sengupta and Dahl's (2008) overseas study findings, that males respond more positively to sexuality in advertisements than females do.

\subsection{Appropriateness of the advertisement to the product}

Several researchers (e.g. Veloutsou \& Ahmed, 2005; Ouwersloot \& Duncan, 2008) have found that a link between the product and sex is necessary for positive results from advertising using sexual appeals. This part of the study sought to identify whether respondents believed the advertisements were appropriate to the product being advertised, that is, what Sengupta and Dahl (2008) describe as having 'product relevance'.

Table 5

Statement 3: this advertisement was appropriate for the product type

\begin{tabular}{|l|c|c|c|c|c|} 
& $\begin{array}{c}\text { Advertisement } \\
\text { 1: FRT }\end{array}$ & $\begin{array}{c}\text { Advertisement } \\
\text { 2: Durex }\end{array}$ & $\begin{array}{c}\text { Advertisement } \\
\text { 3: Peugeot }\end{array}$ & $\begin{array}{c}\text { Advertisement } \\
\text { 4: Tom Ford }\end{array}$ & $\begin{array}{c}\text { Advertisement } \\
\text { 5: Gucci }\end{array}$ \\
\hline Per cent & Per cent & Per cent & Per cent & Per cent \\
\hline 1. Strongly agree & 0 & 35 & 4 & 11 & 4 \\
\hline 2. Agree & 2 & 35 & 23 & 16 & 9 \\
\hline 3. Neither A nor D & 4 & 11 & 19 & 11 & 18 \\
\hline 4. Disagree & 37 & 14 & 32 & 26 & 37 \\
\hline 5. Strongly disagree & 58 & 5 & 23 & 37 & 33 \\
\hline Mean & 4.51 & 2.33 & 3.46 & 3.56 & 3.68 \\
\hline Std dev & 0.658 & 1.244 & 1.196 & 1.427 & 1.298 \\
\hline
\end{tabular}

As mentioned above, in the focus group discussions, respondents were asked what their immediate reaction to the advertisements was. The second most common theme after too much sexuality, was that the advertisements were inappropriate. Inappropriateness related mostly to the relevance of sexuality to the brand or product. For example, respondents commented 'I just don't think that it is appropriate to these products' and 'some of them lack brand relevance'.

For all except the Durex advertisement, 
where 70 per cent of respondents said there was a fit between the sexual appeal and the product, respondents felt that the sexual appeal was not appropriate or linked. This sentiment was particularly strong for the French Rugby Team advertisement, where 95 per cent of respondents indicated disagreement that the appeal was appropriate to the product. This advertisement generated a great deal of discussion in the focus group. Some respondent comments were 'This is just something you don't want to see'; 'I just don't associate rugby with homos'; and 'Rugby is seen as this masculine and butch sport, and then these guys just look like pansies'. Thus the 'inappropriateness' appears to relate more to the fact that the advertisement was perceived to imply homosexuality rather than sexuality per se. Despite these comments, it is interesting that there was more support for there being a fit or link between the product and the sexual appeal in the discussions than is reflected in the quantitative data above. For example, some respondents commented that 'sportsmen have become sex icons' and the link is that 'rugby players have good bodies and women like that'. Gender differences were clearly evident here. These are reported on below.

The majority of respondents (55 per cent) indicated that they did not think the Peugeot advertisement was appropriate, and in the focus-group discussion they said that the use of a sexual appeal was not appropriate as sex has no link to cars. For the Tom Ford advertisement, most respondents (63 per cent) also did not believe that the advertisement was appropriate for the product. However, discussion was split, with some respondents saying perfume has no link to sex while others said 'perfume is an aphrodisiac'; 'when you wear perfume, you feel more sexy'; and 'you buy perfume to smell good to attract the opposite sex'. For the Gucci advertisement, 70 per cent of respondents disagreed that the advertisement was appropriate. However, in the discussions some respondents in the focusgroup discussion said that there may be a link to sex because 'women buy Gucci to look good ... to attract men' and Gucci uses 'sexual materials ... like satin and silk'. Others, however, said there is no link and thus the use of sexual appeals for Gucci is inappropriate.

When respondents were asked whether they believed sexual appeals should be used when the link to the product is non-existent or weak, 47 per cent of responses were 'No, there must be a link' for sexual appeals to be used. However, 29 per cent of responses were of the opinion that whether there was a 'link or not, sex sells'. Another response was that it depended on the target audience.

Thus the use of sexual appeals being perceived as appropriate does seem to be dependent on the product and the relevance or link between the product and sex, but results are not clear-cut. Gender differences were again apparent.

Table 6

Gender differences: statement 3: this advertisement was appropriate for the product type

\begin{tabular}{|c|c|c|c|c|c|c|c|c|c|c|}
\hline & \multicolumn{2}{|c|}{$\begin{array}{c}\text { Advertisement } \\
\text { 1: FRT }\end{array}$} & \multicolumn{2}{|c|}{$\begin{array}{l}\text { Advertisement } \\
\text { 2: Durex }\end{array}$} & \multicolumn{2}{|c|}{$\begin{array}{c}\text { Advertisement } \\
\text { 3: Peugeot }\end{array}$} & \multicolumn{2}{|c|}{$\begin{array}{l}\text { Advertisement } \\
\text { 4: Tom Ford }\end{array}$} & \multicolumn{2}{|c|}{$\begin{array}{l}\text { Advertisement } \\
\text { 5: Gucci }\end{array}$} \\
\hline & $\mathbf{F}$ & M & $\mathbf{F}$ & M & $\mathbf{F}$ & M & $\mathbf{F}$ & M & $\mathbf{F}$ & M \\
\hline Mean & 4.32 & 4.85 & 2.54 & 1.95 & 3.32 & 3.70 & 3.86 & 2.95 & 4.08 & 2.95 \\
\hline Std dev & 0.709 & 0.366 & 1.325 & 0.999 & 1.226 & 1.129 & 1.308 & 1.468 & 1.038 & 1.432 \\
\hline Mann-Whitney sig score & & 0.002 & & 0.114 & & 0.276 & & 0.019 & & 0.003 \\
\hline
\end{tabular}

As can be seen from the Mann-Whitney scores, there were significant differences in responses between males and females for the French Rugby Team, Tom Ford and Gucci advertisements. For the Durex advertisement, both males and females felt that the advertisement was appropriate to the product. The product was relevant to sex. For the Peugeot advertisement, both genders generally were neutral on the relevance of a sexual appeal to the product.

However, for the French Rugby Team advertisement, males felt very strongly (mean of 4.85 and standard deviation of 0.366 ) that the use of sexual appeal was not appropriate to this product. While females agreed with males, 
they did not feel nearly as strongly about this $($ mean $=4.32)$. For the Tom Ford and Gucci advertisements, females disagreed with the appropriateness of the advertisements to the product significantly more strongly than males did. Females believed the advertisements were not appropriate while males were neutral.

Thus for sex-related products such as condoms, both males and females agreed that a sexual appeal could be appropriate. However, for products that did not have a strong link to sex, results were mixed. For the Peugeot advertisement, where respondents felt there was not a strong link to sex, respondents were generally neutral to the use of a sexual appeal. In this advertisement mild eroticism was used.

However, where nudity was used as the sexual appeal, as with the French Rugby team and Gucci advertisements, then when the product is not linked to sex, respondents did

further investigation.

It can be concluded that the advertisements which offended the most and appealed the least, that is, the French Rugby Team advertisement, the Tom Ford advertisement and the Gucci advertisement were also those with the greatest amount of nudity and were believed to be most inappropriate to the products being advertised.

\section{9}

\section{Recommendations}

\subsection{Advertising message}

This research indicated that generally the respondents were offended by print advertisements containing sexual appeals and did not find them appealing, particularly if nudity was the form of sexual appeal used, if the advertisement was for a sex-irrelevant product, and if the models were of the same gender as those being targeted by the advertisement. Given the proliferation of sexual appeals in advertisements today, this suggests that advertisers may be damaging their brand and thus should use other forms of advertising instead of sexual appeals in most cases. The two main exceptions would be advertisements that use sexual appeals containing female models and that are targeting men, and sexrelevant advertisements, that is, where sex has not think that a sexual appeal was appropriate. Thus, as was found with Objective 1, nudity is what offends and, in this case, is what makes the use of sexual appeal inappropriate for sexirrelevant products. Thus it seems that where sexual appeal does not have product relevance, then nudity in particular as a sexual appeal is likely to cause a negative response from viewers. Gender, however, also appears to moderate these perceptions, with males being particularly against sexual appeals for sexirrelevant products where males are used in the advertisements, possibly due to homophobia, and females are more against the use of female nudity. The issue of whether the male respondents disliked the advertisements with male models due to the presence of males per se or the presence of two males, the one with an arm around the other, and thus potentially indicating a homosexual relationship, will need relevance to the product such as with condoms. However, even with sex-relevant products, where females may believe the advertisement was appropriate, they did not find it appealing and found the advertisement offensive. Offensive advertisements can cause damage to sales, reputation and ultimately profitability.

If advertisers wish to use sexual appeals then it seems that eroticism is a safer type of sexual appeal than nudity, which generates greater offense. This implies that there is scope for greater use of more suggestive advertising. Reichert (2003) suggests that sexual suggestiveness is a more subtle form of sexual appeals in advertising. The sexual connotation is still present and clear although it is a less controversial form of sexuality (Clow \& Baack, 2007). Advertisers should use sexual appeals only if it will enhance a brand name or product (Clow \& Baack, 2007). In addition, advertisers should use sexual appeals in an interesting rather than distasteful manner, and should also subscribe to widely accepted ethical standards (Clow \& Baack, 2007).

\subsection{Target market for sexual appeals in advertising}

This research has shown that, amongst this student sample, there are significant differences in the extent to which sexual appeals in advertising are offensive, appealing and appropriate. Females were most offended by the advertise- 
ments with a greater extent of female nudity, such as the Tom Ford and Gucci advertisements, but were neutral on the others. With the exception of the Peugeot advertisement, where females were neutral, none of the advertisements appealed to the females. They were neutral on the appropriate-ness of the Durex and Peugeot advertisements, but disagreed that the advertisements were appropriate for the others. Thus overall, the female responses to sexual appeals can be termed neutral to negative and thus not recommended for advertisements targeting women.

There were significant differences between the responses of the female and male respondents in all except the appeal of the Peugeot advertisement, where both genders were neutral, and the appropriateness of the Durex and Peugeot advertisements, where with the Durex advertisement they believed the advertisement was appropriate, and on the Peugeot advertisement they agreed that it was slightly inappropriate. For the rest, females were more offended, found the advertisements less appealing and less appropriate than males did. The exception was the French Rugby Team advertisement, where the reverse was true. This finding indicated that male perceptions differed according to the gender of the model in the advertisement. Thus the use of male model sexuality in advertisements aimed at men or even viewed by men for purchase for women, is likely to be viewed in a negative light, and thus is not recommended. This is supported by Israel and Strassberg's (2009) research, that found that men were more uncomfortable than women in finding samesex models sexually appealing.

The use of female sexual appeal advertisements aimed at men, however, may be effective. If advertisers use sexual appeals in their advertising messages they need to ensure that their product is targeted at the right market and that the selected market finds this type of advertising appealing. Failure to do so may result in consumers responding negatively towards the brand and this could diminish the consumer's opinion of the brand. This will ultimately affect the overall brand image and may decrease brand equity and loyalty.

\section{0}

\section{Limitations of the study}

The first limitation was the small and somewhat uneven sample on a gender basis. However, the purpose of this research was to explore, through qualitative and quantitative data collection, the impact on, and reactions of, respondents to advertisements using sexual appeals. Focus groups allowed for this triangulation design, but limited the total sample size due to time and resource constraints. Further research with a larger sample would add value and improve the generalisability of this exploratory research. A further limitation and suggestion for future research would be to look at possible cultural differences, and to compare these findings with data collected in other regions in South Africa.

\section{1}

\section{Conclusion}

In conclusion, this research indicated generally negative attitudes towards sexual appeals in print advertising. However, there were exceptions depending on the product type, the type of sexual appeal and the target audience. Sex-relevant products such as condoms may successfully use sexual appeal, although females, while believing this appeal may be appropriate, are still unlikely to find the advertisement appealing and may still find it offensive. Nudity as a form of sexual appeal is a greater cause of offensiveness than eroticism and this is particularly true for same sex models, that is, females are more offended by sexual appeals with nude females, and males are even more offended by sexual appeals containing male models. Thus overall, sexual appeals may be effective when using female models in an advertisement targeting men but women are unlikely to find any form of sexual appeal effective. Sexual appeals should be used with caution. 


\section{Acknowledgements}

Special thanks go to the SAJEMS reviewers who provided valuable and constructive feedback leading to the improvement of the article.

\section{References}

BELCH, G. \& BELCH, M. 2007. Advertising and promotion: an integrated marketing communications perspective. $\left(7^{\text {th }}\right.$ ed.) New York: McGraw-Hill Irwin.

BIRD, D., CALDWELL, H. \& DEFANTI, M. 2008. Differences in perceptions of print advertising for men's fragrances. Competition Forum, 6(1):209-218. Available at: http://proquest.umi.com.ezproxy.ukzn.ac.za [accessed 2009-04-17].

CEBREZYSKI, G. 2000 Sex or sexy? The difference is that one sells, and the other doesn't. Nation's Restaurant News, 34(11):14. Available at: http://proquest.umi.com.ezproxy.ukzn.ac.za [accessed 2009-02-27].

CLOW, K. \& BAACK, D. 2007. Integrated advertising promotion and marketing communications. $\left(3^{\text {rd }}\right.$ ed.) New Jersey: Prentice Hall.

CORDER, G. \& FOREMAN, D. 2009. Nonparametric statistic for non-statisticians: a step by step approach. Canada: Wiley.

DUNCAN, T. 2002. IMC: Using advertising and promotion to build brands. New York: McGraw-Hill Irwin. GRATTON, C. \& JONES, I. 2004. Research methods for sports studies. London: Routledge.

ISRAEL, E. \& STRASSBERG, D.S. 2009. Viewing time as an objective measure of sexual interest in heterosexual men and women, Archives of Sexual Behaviour, 38:551-558.

JONES, S. \& REID, A. 2010. The use of female sexuality in Australian alcohol advertising: public policy implications of young adults' reactions to stereotypes. Journal of Public Affairs, 10(1/2):19. Available at: http://proquest.umi.com/pqdweb?did=2022150451\&sid=4\&Fmt=2\&clientId=30060\&RQT=309\&VName=P QD [accessed 2010-11-16].

LATOUR, M. \& HENTHORNE, T. 1994. Ethical judgments of sexual appeal in print advertising. Journal of Advertising, 23(3):81-91. Available at: http://proquest.umi.com/pqdweb?did=23245\&sid=1\&Fmt=3\& clientId=30060\&RQT=309\&VName=PQD [accessed 2010-11-15].

LIU, F., CHENG, H. \& LI, J. 2009. Consumer responses to sex appeal advertising: a cross-cultural study. International Marketing Review, 26(4/5):501 http://proquest.umi.com/pqdweb?did=1871936991\&sid=1 $\& \mathrm{Fmt}=3 \&$ clientId=30060\&RQT $=309 \& \mathrm{VName}=\mathrm{PQD}$ [Accessed 2010-11-12].

LIU, F., LI, J. \& CHENG, H. 2006. Sex appeal advertising: gender differences in Chinese consumers responses. Asia Pacific Journal of Marketing and Logistics, 18(1):19-29. http://proquest.umi.com/pqdweb? $\mathrm{did}=1007271001 \& \operatorname{sid}=1 \& \mathrm{Fmt}=4 \& \mathrm{clientId}=30060 \& \mathrm{RQT}=309 \&$ VName=PQD : [Accessed 2010-11-12].

LOMBARDOT, E. 2007. Nudity in advertising: what influences on attention-getting and brand recall. Recherche et Application en Marketing, 22(4):23-42. Available at: http://cat.inist.fr/?aModele=afficheN\& cpsidt $=20108203$ [accessed 2010-11-15].

MARKS, D. \& YARDLEY, L. 2004. Research Methods for Clinical Health Psychology. London: SAGE.

MOYER, D. 2003. Selling sin: the marketing of socially unacceptable products $\left(2^{\text {nd }}\right.$ ed.) New York: Praeger.

NEUMAN, W.L. 2006. Social research methods. Pearson Education Inc.: Boston

OUWERSLOOT, H. \& DUNCAN, T. 2008. Integrated marketing communications. Berkshire: McGraw-Hill.

PAARSONEN, S., NIKUNEN, K. \& SAAREMAA, L. 2007. Pornification: sex and sexuality in media culture. New York: BERG.

POLIT, D. \& BECK, P. 2004. Nursing research: principles and methods. ( $7^{\text {th }}$ ed.) Philadelphia: Lippincott Williams \& Wilkins.

PUTREVU, S. 2008. Consumer responses towards sexual and nonsexual appeals: the influence of involvement, need for cognition (NFC) and gender. Journal of Advertising, 37 (2):57-69. Available at: http://proquest.umi.com/pqdweb? $\mathrm{did}=1564207401 \&$ sid=1\&Fmt=3\&clientId=30060\&RQT=309\&VName=P QD [accessed 2010-11-15].

REICHERT, T. 2003. The online source for sex in advertising research, history and commentary. 17 Paragraphs. Available at: http://www.sexinadvertising.com [accessed 2010-11-14]. 
REICHERT, T., LAMBIASE, J., MORGAN, S., CARSTARPHEN, M. \& ZAVOIND, S. 1999. Cheesecake and beefcake: no matter how you slice it, sexual explicitness in advertising continues to increase. Journalism and Mass Communication, 76(1):7-21. Available at: http://proquest.umi.com.ezproxy.ukzn.ac.za [accessed 2009-01-17].

SENGUPTA, J. \& DAHL, D.W. 2008. Gender-related reactions to gratuitous sex appeals in advertising. Journal of Consumer Psychology, 18:62-78.

SENGUPTA, J. \& GORN, G.J. 2002. Absence makes the mind grow sharper: effects of element omission on subsequent recall. Journal of Marketing Research, 39(2):186-201.

SHIMP, T. 2008. Advertising, promotion and other aspects of integrated marketing communication $\left(8^{\text {th }} \mathrm{ed}\right.$.) South-Western Pub.

TAFLINGER, R. 1996. Taking advantage. 47 Paragraphs. Available at: http://www.wsu.edu:8080/ taflinge/ sex.html [accessed 2010-11-15].

TREHAN, M. \& TREHAN, R. 2007. Advertising and sales management. Delhi: VK Publications.

VELOUTSOU, C. \& AHMED, S. 2005. Perception of sexual appeal in print adverting by young-female anglo-saxon and second generation asian-islamic British. Journal of Promotion and Management, 11:91-113. Available at: http://eprints.gla.ac.uk/4629/1/4629.pdf [accessed 2010-11-16].

WALKER, R. 2003. Puma's problem: the racy photo that's got a sneaker company steamed. 9 Paragraphs. Available at: http://www.slatetv.org/id/2081467/ [accessed 2011-07-27].

WELLS, W., BURNETT, J. \& MORIARTY S. 2000. Advertising: principles and practice (5 $5^{\text {th }}$ ed.) New Jersey: Prentice Hall.

WELMAN, C., KRUGER, F. \& MITCHELL, B. 2005. Research methodology (3 ${ }^{\text {rd }}$ ed.) South Africa: Oxford. 